\title{
THE EFFECTS OF BANKRUPTCY AND REORGANISATION PLAN ON THE ECONOMIC SYSTEM OF SERBIA
}

\author{
Aničić Dušan ${ }^{1}$, Nataša Simić2 ${ }^{2}$ Vesna Petrović ${ }^{3}$ \\ ${ }^{1}$ DSN Konsalting, Belgrade, Serbia \\ ${ }^{2,3}$ Faculty of entreneurship and real estate management, Union University-Nikola Tesla, Belgrade \\ anicic.dusan@yahoo.com, nsimic68@gmail.com, al.petrovicpn@gmail.com
}

\section{Professional Paper doi:10.5937/jouproman6-16561}

\begin{abstract}
Bankruptcy proceedings have widerange implications for the economic system of the country, from unemployment, competitiveness, the reform process, etc; in a word, it has broad social effects. Therefore, the law should provide effective, simple and flexible management of the bankruptcy proceedings, with precisely established deadlines and clear consequences of the actions taken. The role of the state in bankruptcy proceedings is to preserve general social interest, stability and safety of the legal and economic systems. Reorganisation of the enterprises should lead to financial recovery of the debtor with the aim of its continuing to do business, settle debts (completely or partially) and become solvent and profitable afterwards. The success of reorganisation depends, among other things, on adequate financial analysis of the debtor. Due to a large number of companies (and considerable assets) in the process of bankruptcy and reorganisation, these processes are very important for the development of the economic system in Serbia.
\end{abstract}

Key words: bankruptcy, reorganisation, economic system, Serbia

\section{Introduction}

Great attention is paid to the affairs of bankruptcy proceedings even in international frameworks, from the most developed countries to the countries in transition. During periods of stable economic growth and high credit activity, the bankruptcy function was often reduced to clearing the market from insolvent enterprises, and the consequences of bankruptcy on social conditions in society were not taken into account. However, frequent economic crises in the world have caused the need to redefine the role and importance that bankruptcy has on the development of the economic system of the country. The phenomena such as accelerating technological changes, a decline in demand for certain products, financial breaks of large proportions, etc, influenced the application of outdated and inflexible regulation which further increased the crisis. Globalisation and business internalisation also caused modernisation and harmonisation of regulations in bankruptcy proceedings in different countries.

Bankruptcy regulations impose responsible behaviour on business entities towards business partners and the environment, make business conditions similar for all, but also offer a chance for company business revitalisation through its business and financial reorganisation. The range of company reorganisation includes most of the areas of its business, such as management, marketing, organisation, accounting, finances, personnel aspect. All these measures are used with the aim of regulating relations between creditors and other business partners, as well as financial and business recovery. Reorganisation tries to achieve maximum effects for all participants in the procedure, such as creditors, employees, the state, local authorities and others. 
Due to a large lag in the economic development compared to the developed world, as well as a number of insolvent companies, the issue of bankruptcy and company reorganisation in Serbia has a lot of influence and importance for the complete economic trends and the domestic product of the country.

\section{Bankruptcy regulations in Serbia}

Bankruptcy is most often defined as a state in which a debtor cannot fulfill its obligations to creditors, and on the other hand, the enforcement of the claims of all creditors against the property of debtors which leads to the loss of legal entity for the bankruptcy debtor (Spirovic, 2004).

There are numerous implications of bankruptcy for the economy of any country, such as unemployment, competitiveness, social status of the population, reform process, etc. This is the reason for a lot of questions and doubts in the world practice and expert considerations regarding bankruptcy legislation construction and application.

For example, whether the law should promote discipline, take the inefficient and incompetent out of the game, or it should be more tolerant and therefore encourage entrepreneurial spirit in terms of more willingness for taking risks? Should the law have larger social effects in the society or does it have the aim only to solve individual cases? Does it take employment effects into consideration? Does it favour informal, out of court arrangements or formal reorganisation processes within the court? What is the role of the state? (Wood, 1999).

The conditions and way of initiating and conducting bankruptcy of legal entities in the Republic of Serbia are regulated by the Bankruptcy Law (Official Gazette RS no. 104/ 09, 99/11 - , 71/12 - the Constitutional Court decision, 83/14). The aim of bankruptcy is the most favourable collective settlement of bankruptcy creditors by achieving the highest possible worth of the bankruptcy debtor, that is, his property. The law should provide efficient, simple and flexible management of the bankruptcy proceedings, with accurately established deadlines and clearly defined consequences of these actions.

Bankruptcy proceedings are conducted through bankruptcy or reorganisation. Bankruptcy includes the settlement of creditors through the sale of the complete property of the debtor as a legal entity. Reorganisation means the settlement of creditors according to the adopted reorganisation plan through the redefinition of relations between debtors and creditors, the changes in status of the debtor or in any other way planned by the reorganisation.

Bankruptcy proceedings are opened when at least one of the reasons for bankruptcy are determined, and they are: 1) more permanent payment inability; 2) incapacitating payment; 3) excessive indebtedness; 4) failure to comply with the adopted reorganisation plan, reorganisation plan is made by fraud or in an illegal way.

There is more permanent payment inability if a legal entity cannot respond to its obligations within 45 days from the time they become due or completely suspends all payments during a continuous 30 day period. Incapacitating payment exists if the bankruptcy debtor shows that it is probable that it will not be able to pay its already existing obligations when they become due. Excessive indebtedness exists if the bankruptcy debtor's property is less than its liabilities. Failure to comply with the reorganisation plan exists when the bankruptcy debtor does not act according to the reorganisation plan or acts contrary to the reorganisation plan which significantly threatens its implementation. 
Bankruptcy proceedings are initiated by the petition of the creditor, debtor or liquidation administrator (authorised petitioners). After the decree of bankruptcy, the bankruptcy administrator starts and conducts the sale of the entire property or part of the debtor's assets. Assets can be sold by public auction, public tender or direct negotiation.

The Law Amending the Law on Bankruptcy Supervision Agency, which came into force on 4th November 2015, entrusted Bankruptcy Supervision Agency with the performance of bankruptcy administrators in bankruptcy proceedings conducted against legal entities with majority public or social capital, as well as the proceedings where during the bankruptcy proceedings there is a change in the ownership structure of the debtor, so that the debtor becomes a legal entity with a majority of public capital according to the Law on Bankruptcy. When this act came into force, the Agency took over all the rights and obligations, cases, equipment, resources and archives from the Privatisation Agency, all of which are in the function of conducting the work determined by this law.

According to the data available at Bankruptcy Supervision Agency, dated 1st November 2017, there are the total of 2081 active bankruptcy proceedings in the territory of the Republic of Serbia. At the same time, in the period between 1st January 2017 and 1st November 2017, 289 bankruptcy proceedings were opened and 614 bankrupcy proceedings were suspended. In the territory of the Republic of Serbia 3881 bankruptcy proceedings were concluded until 1st October 2017 as follows: 291 procedure until 2008, 197 during 2008, 164 during 2009, 316 during 2010, 507 during 2011, 640 during 2012, 468 during 2013, 340 during 2014, 389 during 2015, 351 during 2016 and 218 procedures during 2017 ( Bankruptcy Supervision Agency, 2017).

According to the Bankruptcy Supervision Agency, total average duration for 6576 bankruptcy procedures is two years, ten months and nineteen days (active, suspended and concluded), which speaks for itself about the bankruptcy proceedings inefficiency in Serbia and great damage such delays cause. Also, we should bear in mind the various interests of the participants in the bankruptcy proceedings: for example, business partners (buyers, suppliers) mainly have the interest that the bankruptcy debtor continues working because it will affect their future business in a greater amount, while the interest of banks is mainly opposite. The interest of local authorities is also that the company continues working because certain companies are the carriers of employment and budget revenues in small towns. On the other hand, the state acts indirectly through the judicial system, and directly through legislative activities and regulatory bodies, and tries to preserve general social interest, stability and safety of the legal and economic system. In the conditions when a large share of the capital is the property of the state (socially owned property) and there are huge accumulated debts between the companies and the state, the strict application of bankruptcy regulations would destroy a large part of the economy at one moment, with a lot of negative effects for the employed people as well as general social aspect (Falke, 2003).

\section{Reorganisation plan - a modern approach to the issues of bankruptcy}

Reorganisation is conducted if it provides more favourable settlement for creditors in comparison to bankruptcy, especially if there are economically justified reasons for continuation of the debtor's business. 
Reorganisation is conducted according to the reorganisation plan which is drawn up in writing. A reorganisation plan can be submitted simultaneously with the petition for the start of bankruptcy proceedings or after the opening of bankruptcy proceedings according to this law. If the reorganisation plan is submitted at the same time as the petition for the start of bankruptcy proceedings, its name is changed into the pre-pack reorganisation plan, where its contents and the procedure applied are determined according to the provisions of the law that determine the issue.

The significance of reorganisation is increasing in more often and stronger financial crisis in the world, especially in the economies of the countries in transition. Reorganisation is an attempt to prevent liquidation of the company that has become insolvent, that is, unable to settle its obligations. Reorganisation should lead to the economic recovery of the debtor with the aim of its continuing to do business, repaying debts (completely or partially) and becoming solvent and profitable after reorganisation. Reorganisation process can be very dynamic and turbulent under the influence of numerous external and internal factors, and it can lead to various changes in ownership and debtor-creditor relationship, the position of management and empolyees, company organisation, etc. The most important criterion for the management of the reorganisation process is maximising its value for all the participants as well as the complete economic system (Malbasic, 2005).

Among other things, reorganisation plan includes a list of measures and resources for the realisation of the plan, as well as a detailed description of the measures to be undertaken and the way of conducting reorganisation. The companies without a business perspective, those which are the generators of an insolvency chain, should not be saved at all costs because it would only mean prolonging the agony they are in, with harmful consequences of a wider range. The implementation of reorganisation plan offers the opportunity for the debtor, and the time necessery for the stabilisation of its business. There is a large number of organisational, legal and economic measures at debtor's disposal to help solve the insolvency problem and settle the creditors in an acceptable way. Some of these measures are: preorientation to new programme of production or services, introduction of new technologies leading to a significant reduction in costs, entrance to new markets, finding a domestic or foreign strategic partner, etc. Especially important measures for the realisation of reorganisation plan are prediction of repayment in installments, change of maturity rates, interest rates or other terms of loans, credits or other claims or collaterals.

Besides the elements included in the reorganisation plan, pre-pack reorganisation plan (PRP) contains signed statements of major creditors according to the value of claims in every class predicted by the plan that they are familiar with the contents of reorganisation plan and ready to access a hearing for voting in the event of reorganisation plan or vote in writing. It also includes the extraordinary auditor's report on bookkeeping with the state determined no later than 90 days prior to the day of submitting the pre-pack reorganisation plan to the court, with the review of all claims and percentage shares of each creditor in the appropriate class of the plan. Also, the auditor or bankruptcy administrator's statement about a feasibility of the pre-pack reorganisation plan is a compulsory element.

It is necessary to use financial analysis methods such as ratio numbers (indicators of liquidity, turnover inventory, capital structure indicators, etc.), 
cash-flow and fund-flow analysis, balance sheet analysis, profit and loss analysis (maturity of assets and liabilities), net working capital, property usage efficiency, etc. The efficiency of property management is directly connected to liquidity, solvency and profitability of the company and therefore the turnover analysis is in the centre of the ratio analysis in the financial reports (Anicic et al, 2017). Of course, the adequate system of accounting reporting in the function of business decision making is implied. The issues of organisational structure and the ability of adapting to the influence of environment, the ability to introduce and apply new technologies, the efficiency of the marketing mix (product, price, distribution and promotion), personnel structure, etc.

The efficiency of the process of reorganisation largely depends on whether the reasons that led to the insolvency of the company are determined in the right way. The analysis of financial indicators can often point to the causes, especially if the analysis is conducted for several consecutive years. The important items are the analysis of profit decline (income decrease or cost increase, cost structure, cost calculation, cost division into fixed and variable costs and their influence on profitability, etc), ratio of inventories, collection of receivables average duration, etc. Cash flow analysis provides a picture of insolvency, that is, non-compliance of inflows and outflows of money even though the company has a satisfactory profitability.

The causes of difficult financial situation of a company are numerous. They can be in bad macroenomic environment, general insolvency of the economy, low purchasing power of the population, situation in the specific economic sector, inability to adapt to the changes in the environment and market demands, lack of personnel, etc. Simultaneous activity of several negative factors is characteristic for Serbia during the whole period of transition. The inadequate economic policy based on the neoliberal concept after the year 2000 has also had a significant impact, but it completely neglected the conditions of the economy after the international sanctions, bombing and destruction of significant economic capacities.

\section{Conclusion}

The issues of the bankruptcy proceedings are receiving increasing significance in the conditions of great economic disturbances, under the influence of globalisation and business internalisation, as well as harmonisation of legal regulations between countries. At the beginning, the bankruptcy regulations were imagined as a way of introducing discipline for insolvent companies, but later, social effects on the economic system of the country are taken into consideration under the influence of various factors. Along other regulations in the field of economy, bankruptcy regulations constitute the basis of economic legislative reform with the aim of harmonisation of business regulation in Serbia with the EU regulations.

Bankruptcy proceedings and reorganisation procedures are very slow in Serbia, which produces numerous negative effects not only for the company and its employees but also the wider community. The fact that the average duration period of bankruptcy proceedings in the transitional period is almost three years points to greater negative social consequences on the economic development of the country. Time factor is very important, as well as the recognition of companies with an opportunity to return successfully to market business through reorganisation process. 
Special attention should be paid to the companies which do business in a small local environment and therefore are holders of employment, development and budget for local authorities.

\section{References:}

Bankruptcy Supervision Agency, the statistics of bankruptcy proceedings, Belgrade, December 2017.

Aničić, J., Simić, N., Petrović, V., Aničić, D., (2017) Financial aspects of current assets management in Serbian economy, Journal of process management - new technologies international, Volume 5, Issue 2, str. 36-44.
Falke, M., (2003) Insolvency Law Reform in Transition Economies, Berlin

Malbašić, V., (2005) Reorganizacija kao mera za sprečavanje stečaja, Radni dokument, Srpski ekonomski forum, Beograd

Spirović, Jovanović, L., (2004), „ Trgovinsko pravo“, Beograd, str. 204.)

Zakon o Agenciji za licenciranje stečajnih upravnika (,Službeni glasnik RS“, br. 84/04, $104 / 09$ i 89/15)

Wood, R., Ph, (1999). Insolvency Law and the Legal framevork, Washinhton, D.C., September 1999.) 